\title{
Who Can Be President of the United States?: Candidate Hillary Clinton and the Problem of Statutory Qualifications
}

\author{
Seth Barrett Tillman* \\ Maynooth University Department of Law, Ireland
}

\begin{abstract}
Qualifications for public office restrict democratic choice, but such restrictions have a long pedigree in many jurisdictions. For example, the U.S. Constitution sets out qualifications for elected federal officials: i.e., Representative, Senator, President, and Vice President. Qualifications for those positions include provisions relating to age, citizenship, and residence. It has been long debated whether these textual qualifications are exclusive (i.e., floors and ceilings) or whether they are merely floors, which can be supplemented by additional qualifications imposed by Congress or by the States.

Once again, this issue has become topical. Former Secretary of State Hillary Clinton is a prominent candidate in now-ongoing Democratic Party primary elections. These primaries select delegates to a national convention which will choose the Democratic Party's candidate for the 2016 popular presidential election. It has been alleged that, during her term as Secretary of State, Clinton violated a provision of the federal statute mandating government record keeping. 18 U.S.C. \$ 2071 provides: "Whoever, having the custody of any ... record ... willfully and unlawfully conceals, removes, mutilates, obliterates, falsifies, or destroys the same ... shall forfeit his office and be disqualified from holding any office under the United States."

This Article addresses two interesting interpretive challenges posed by Section 2071. First, does Section 2071's "office under the United States" language reach the presidency? Second, if Section 2071's "office under the United States" language encompasses the presidency, is the statute constitutional? In other words, does Congress have the power to create additional qualifications for the presidency?
\end{abstract}

\footnotetext{
* Lecturer, Maynooth University Department of Law, Ireland. Roinn Dlí Ollscoil Mhá Nuad. I thank Professors Albert, Beck, Kalt, Samahon and Mr. Brownell for their thoughtful comments and other help.
} 


\section{CONTENTS}

I. Introduction: The Key Legal Issues .................................. 97

II. What is the Scope of the Statute? .................................... 99

A. The Legal Populist ............................................................ 101

B. The Historical Approach................................................ 104

1. President George Washington's Gift from the French Ambassador .................................................................. 104

2. Secretary Hamilton's List............................................ 108

3. Post-Civil War Scholarship ......................................... 109

C. Presumptions of Statutory Interpretation ............................ 110

1. General "Office" Language does not Reach the Presidency............................................................. 110

2. Interpretations of Statutory Language Restricting the Scope of Democratic Choice are not Favored .............. 112

III. If the Statute Reaches the Presidency, is it Constitutional?

A. Judicial Authority............................................................... 113

B. Constitutional Structure ..................................................119

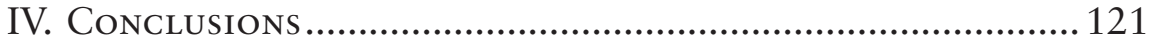




\section{Introduction: The Key Legal Issues}

Constitutions, statutes, and regulations create public offices, and frequently such legal instruments also create qualifications for those offices. When positive law creates qualifications for elected positions, these restrictions limit the scope of democratic choice. ${ }^{1}$ Nevertheless, such restrictions on democratic choice have a long pedigree ${ }^{2}$ in a variety of jurisdictions. ${ }^{3}$ Adjudications relating to qualifications to public office are not uncommon. ${ }^{4}$ Likewise, in the United States, the Constitution sets out qualifications for elected federal officials: i.e., Representatives, Senators, President and Vice President. Such qualifications include, among others, provisions relating to age, citizenship, and residence. ${ }^{5}$ Courts and commentators have long debated whether the

1 See Josh Chafetz, Democracy's Privileged Few: Legislative Privilege and Democratic Norms in the British and AmErican Constitutions 170 (2007). Throughout this Article, I treat all constitutional restrictions on a candidate's being elected or holding office as "qualifications." It may be that some of these constitutional provisions are better characterized as "eligibility requirements," as opposed to a true "qualification." A candidate who lacks a qualification for an office is capable of being elected, and the candidate may assume office if she becomes qualified after the election but prior to the start of the term for which she was elected (or, even, if she becomes qualified within a reasonable time after the start of the term). On the other hand, where a candidate lacks an eligibility requirement, the candidate is incapable of being elected, and all votes cast for such a candidate are void. In such a situation, even if the candidate subsequently meets the eligibility requirement prior to the start of the term for which she was "elected," the candidate cannot assume office. See, e.g., State v. Howell, 126 P. 954, 955-56 (Wash. 1912) (Gose, J.) (holding that constitutional restrictions relating to "eligibility" relate to the capability of the candidate to be chosen at the time of election); Luther Stearns Cushing, Elements of the Law and Practice of Legislative Assemblies in the United States of America § 175, at 66 (Boston, Little, Brown and Co. 2d ed. 1866) ("If an election is made of a person, who is ineligible, that is incapable of being elected, the election of such person is absolutely void ....").

2 See 2 John Hatsell, Precedents of Proceedings in the House of Commons 1-80 (London, Luke Hansard and Sons new ed. 1818) (discussing seventeenth-century and eighteen-century House of Commons qualifications).

3 E.g., Australian Constitution ss 43-45 (qualifications for members of Parliament); India Const. art. 58 (qualifications for President), arts. 84, 102 (qualifications for members of Parliament).

4 See, e.g., Sykes v Cleary (1992) 176 CLR 77 (Austl.) (adjudicating parliamentary candidates' qualifications); In re Parliamentary Election for Bristol S.E., [1961] 3 All E.R. 354 (Q.B.) (Gorman \& McNair, JJ.) (Eng.) (declaring, after his prevailing in an election, that Anthony Wedgwood Benn, M.P., was disqualified from holding a U.K. House of Commons seat, as a result of his having succeeded to a House of Lords seat which had been held by his late father).

5 See, e.g., U.S. Const. art. II, § 1, cl. 5 ("No Person except a natural born Citizen . . . shall be eligible to the Office of President; neither shall any Person be eligible to that Office who shall not have attained to the Age of thirty five Years, and been fourteen Years a Resident within the United States."); see also, e.g., id. at art. I, $\S 2$, cl. 2 ("No Person shall be a Representative who shall not have attained to the Age of twenty five Years, and been seven Years a Citizen of the United States, and who shall not, when elected, be an Inhabitant of that State in which he shall be chosen."); id. at art. I, § 3, cl. 3 ("No Person shall be a Senator who shall not have attained to the Age of thirty Years, and been nine Years a Citizen of the United States, and who shall not, when elected, be an Inhabitant of that State for which he shall be chosen."); cf., e.g., id. at amend. XII ("[N]o person constitutionally ineligible to the office of President shall be eligible to that of Vice-President of the United States."); $i d$. at amend. XXII ("No person shall be elected to the office of the President more than twice ...."). Compare, e.g., Richard Albert, The Evolving Vice Presidency, 78 TEMP. L. Rev. 811, 857 (2005) ("[I]t appears that a two-term President may not, as a matter of constitutional law, accept the vice presidential nomination."), with Bruce G. Peabody \& Scott E. Gant, The Twice and Future President, 83 MinN. L. REv. 565, 620 (1999) (" $[I]$ t therefore cannot be said that the Twelfth Amendment prohibits a 
qualifications in the Constitution's text are exclusive (i.e., floors and ceilings) or whether they are merely floors, which can be supplemented by additional qualifications imposed by Congress and/or by the States.

Once again, this issue has become topical. Hillary Clinton, a former Secretary of State and former Senator, is a prominent candidate in the upcoming Democratic Party primary elections. These primaries select delegates to a national convention which will choose the Democratic Party's candidate for the November 2016 popular presidential election. It has been alleged that, during her term of service as Secretary of State, Clinton violated a provision of the federal statute mandating government record keeping. ${ }^{6}$ Section 2071 of Title 18 of the United States Code provides:

twice-elected President from serving as Vice President."). See generally Brian C. Kalt, Constitutional Cliffhangers: A Legal Guide for Presidents and Their Enemies 133-57 (2012) (discussing the circumstances, if any, in which a President can hold a third term, and competing views regarding vice presidential qualifications).

It has been suggested from time to time that other constitutional provisions are qualifications or functional qualifications in regard to (some or all) elected federal positions. See, e.g., U.S. Const. art. I, $\S$ 3, cl. 7 (Disqualification Clause); id. at art. I, § 6, cl. 2 (Incompatibility Clause); id. at art. II, § 1, cl. 8 (Presidential Oaths and Affirmations Clause); $i d$. at art. IV, $\S 4$ (Guarantee [of a Republican Form of Government] Clause); id. at art. VI, cl. 3 (Oaths and Affirmations Clause); id. at amend. XIV, $\S 3$ (Insurrection and Rebellion Clause); see also The Federalist No. 52, at 286 (James Madison-but authorship is disputed) (J.R. Pole ed., 2005) (affirming that the Incompatibility Clause is a qualification for House, and by implication also Senate, service). Compare, e.g., Jack Maskell, Cong. Research Serv., R41946, Qualifications of Members of Congress CRS-21 \& n.112 (2015) (suggesting that Senate-imposed disqualification may bar future membership in Congress), Daniel Hays Lowenstein, Are Congressional Term Limits Constitutional?, 18 Harv. J.L. \& PuB. Pol'y 1, 8 (1994) ("[The constitutional] provision permitting disqualification from holding federal office, presumably includ[es] congressional office, as a permissible punishment in impeachment cases . . . ."), and Buckner F. Melton, Jr., Let Me Be Blunt: In Blount, the Senate Never Said that Senators Aren't Impeachable, 33 QuinNIPIAC L. REv. 33, 35-36 (2014) (suggesting that Senate-imposed disqualification may bar future membership in the Senate), with Benjamin Cassady, "You've Got Your Crook, I've Got Mine": Why the Disqualification Clause Doesn't (Always) Disqualify, 32 QuinnIPIAC L. Rev. 209, 287-94 (2014) (Senate-imposed disqualification is a bar against holding the presidency, but not in regard to holding a congressional seat), and Josh Chafetz, Impeachment and Assassination, 95 MinN. L. Rev. 347, 351 \& n.23, 420-21 (2010) (same), with Seth Barrett Tillman, Originalism \& The Scope of the Constitution's Disqualification Clause, 33 QuinNIPIAC L. Rev. 59 passim (2014) (Senate-imposed disqualification extends only to statutory or appointed offices, but not to any constitutionally-mandated or elected positions). Professors Chafetz and Muller have suggested that the Ineligibility Clause is a qualification or a disqualification in regard to holding a congressional seat. Compare CHAFETZ, supra note 1, at 168 (quoting the Ineligibility Clause, i.e., Article I, Section 6, Clause 2, in a discussion on disqualifications), with Derek T. Muller, Scrutinizing Federal Electoral Qualifications, 90 IND. L.J. 559, 564, 567 (2015) (discussing the Ineligibility Clause as a qualification). The clauses of the Constitution controlling elections have also been described as qualifications. See, e.g., Roudebush v. Hartke, 405 U.S. 15, $26 \mathrm{n} .23$ (1972) (Stewart, J.) ("One of those qualifications is that a Senator be elected by the people of his State." (emphasis added)). These other constitutional provisions, whether properly characterized as "qualifications" or not, do not directly concern our analysis of Section 2071 or other purported statutory disqualifications. Finally, must the President be a living human being? See Muller, supra at $563,567-72$ (expounding on qualifications for the presidency and vice presidency, including whether and, by implication, when a purported President must be alive for the purposes of Article II, Section 1, Clause 5); Michael Stokes Paulsen, Is Bill Clinton Unconstitutional? The Case for President Strom Thurmond, 13 Const. Comment. 217, 222 (1996) ("Surely the Chief Justice should refuse to swear in President Gus the Dog, even if the lawfully constituted electoral college chose him.").

6 E.g., Legal Analysis of Former Secretary of State Hillary Clinton's Use of a Private Server to Store Email Records, Cause of Action: Advocates for Government Accountability 1 (Aug. 24, 2015), http://causeofaction.org/assets/uploads/2015/08/Hillary-Clinton-Email-Memo-8.24.15.pdf. 
Whoever, having the custody of any such record, proceeding, map, book, document, paper, or other thing, willfully and unlawfully conceals, removes, mutilates, obliterates, falsifies, or destroys the same, shall be fined under this title or imprisoned not more than three years, or both; and shall forfeit his office and be disqualified from holding any office under the United States. ${ }^{7}$

Section 2071's language poses two interesting interpretive challenges.

First, what is the scope of the statute? In other words, does Section 2071's generally worded "office under the United States" language extend to the presidency?

Second, if Section 2071's general “office under the United States” language fairly encompasses the presidency, is the statute constitutional? In other words, does Congress have the power to create additional qualifications for the presidency beyond those already expressly stated in the Constitution's text?

\section{What is the Scope of the Statute?}

In determining the scope of Section 2071's generally worded "office under the United States" language, we cannot rely on clearly established Supreme Court or other federal judicial authority ${ }^{8}$ because "the application of [Section 2071] to the Presidency has never been tested." 9 Likewise, the courts have not squarely opined on whether the same or closely similar language in other statutes reaches the presidency. ${ }^{10}$ In the absence of good judicial

$7 \quad 18$ U.S.C. $\S 2071$ (b) (1994) (emphasis added).

8 "Office under the State" is a close textual analogue of "office under the United States." However, state case law using "office under the State" is divided. Compare State ex rel. Ragsdale v. Walker, 33 S.W. 813, 814 (Mo. 1896) (Macfarlane, J.) (explaining that an "office under the state" extends to statutory offices), with Willis v. Potts, 377 S.W. 2d 622, 628 (Tex. 1964) (Hamilton, J., dissenting) (explaining that an "office under the state" extends to offices created by state statutes or by the state constitution). See generally 63C Am. Jur. 2D Public Officers and Employees: Persons Subject to Impeachment § 215 (2015) ("In some jurisdictions, a constitutional provision regarding impeachment of state officers relates only to officers provided for in the constitution or elected by the people at large, while in other jurisdictions, a person must be an officer under the state constitution in order to be impeachable." (footnote omitted)). Foreign courts have occasionally struggled with similar questions, i.e., the scope of general "office" language in a statute or constitutional provision. See, e.g., Williams v Commonwealth (2012) 248 CLR 156, 110 (Gummow \& Bell, JJ.) (Austl.); Sykes v Cleary (1992) 176 CLR 77, 95 (Mason, C.J., Toohey \& McHugh, JJ.) (Austl.); Lewis v. Cattle, [1938] 2 All E.R. 368 (K.B.) 371 (Lord Hewart, L.C.J.) (appeal by way of a case stated by justices for the county borough of Stockport) (Eng.) ("There are many offices which are held under His Majesty the holders whereof are not in any proper sense of the words in the service of His Majesty. So also there are many persons in the service of His Majesty who do not in any proper sense of the word hold office under His Majesty."); cf., e.g., Report from the Select Committee on Offices or Places of Profit under the Crown with minutes of EVIDENCE, APPENDICES AND INDEX viii (London, His Majesty's Stationery Office 1941) (investigating "the precise question" of the scope of "office under the Crown").

9 Charles Gordon, Who Can Be President of the United States: The Unresolved Enigma, 28 MD. L. REv. 1, 9 n.71 (1968). Gordon's claim remains just as true today.

10 In United States v. Mouat, 124 U.S. 303 (1888) (Miller, J.), a government employee sought expenses provided by statute. The validity of the employee's claim depended on whether he was an 
authority, and for the purpose of expositional clarity, I focus on three approaches for resolving the interpretive issue: the legal populist approach, the historical approach, and the legal presumptions approach.

"officer[] of the Navy." Id. at 306. Because the Supreme Court determined that the claimant was not an "officer of the United States," ostensibly a wider category than "officer of the Navy," the Court ruled against the claimant. Id. at 307-08. In reaching its decision, the Court held that:

Unless a person in the service of the government, therefore, holds his place by virtue of an appointment by the president, or of one of the courts of justice or heads of departments authorized by law to make such an appointment, he is not strictly speaking, an officer of the United States.

Id. at 307 (emphasis added). The Mouat Court clearly identified officer of the United States with appointed positions, not elected ones. This would seem to mean that the President is not an "officer of the United States." Moreover, Mouat is not an outlier. See also, e.g., Free Enter. Fund v. Pub. Co. Accounting Oversight Bd., 561 U.S. 477, 497-98 (2010) (Roberts, C.J.) ("The people do not vote for the 'Officers of the United States.' Art. II, § 2, cl. 2. They instead look to the President to guide the 'assistants or deputies ... subject to his superintendence."' (quoting The Federalist No. 72, supra note 5, at 386 (Alexander Hamilton))); Motions Sys. Corp. v. Bush, 437 F.3d 1356, 1372 (Fed. Cir. 2006) (Gajarsa, J., concurring in part and concurring in the en banc judgment) ("It is plain that the President is not an 'officer of the United States' for Appointments Clause, Commission Clause, or Oath of Office Clause purposes.”); Ruth C. Silva, The Presidential Succession Act of 1947, 47 Mich. L. Rev. 451, 475 (1949) (“"Officers of the United States' are appointed by the President and the Senate, by the President alone, by the department heads, or by the courts. Officers in the constitutional sense are not elected by the electoral colleges."). Of course, even if the President is not an "officer of the United States," he might be an "officer under the United States," unless the latter is a subset of the former or unless the two categories are coextensive. Professors Akhil and Vikram Amar have taken the position that the two categories are coextensive. See Akhil Reed Amar \& Vikram David Amar, Is the Presidential Succession Law Constitutional?, 48 Stan. L. Rev. 113, 114-15 (1995) ("At various points the [Constitution] refers to 'Officers of the United States,' to 'civil Officers of the United States,' to 'civil Office under the Authority of the United States,' to 'Office under the United States,' and to 'Office of Trust or Profit under the United States.' As a textual matter, each of these five formulations seemingly describes the same stations (apart from the civil/military distinction) - the modifying terms 'of,' 'under,' and 'under the Authority of' are essentially synonymous." (emphasis added) (footnotes omitted)). If the Amars' intuition on this textual issue is correct, if "office under the United States" and "officers of the United States" are "synonymous," then, per Mouat and its progeny, the presidency is neither an officer of nor under the United States. But see AkHIL Reed Amar, The Law of the Land: A Grand Tour of our Constitutional Republic 332 n.8 (2015) (discussing the Incompatibility Clause, and noting that "[t]he presidency is an 'office under the United States."' (emphasis added)); but see also AKHIL REED AMAR, AMERICA's CONSTITUTION: A BIOGRAPHY 171 (2005) (“The instant such a [legislative leader] became acting president, he would thereby 'hold[]' an 'Office under the United States' ....”' (emphasis added)); but cf. Amar \& Amar, supra at $136 \mathrm{n} .143$ (arguing that an acting President is an "officer of the United States").

In Burton v. United States, 202 U.S. 344 (1906) (Harlan, J.), the Supreme Court adjudicated the scope of a statutory provision in which as a consequence of conviction, a party is precluded from "holding any office of honor, trust, or profit under the government of the United States." Id. at 360. The Court reasoned that such a conviction did not bar a person from a Senate seat.

The seat into which [the defendant-senator] was originally inducted as a Senator from Kansas could only become vacant by his death, or by expiration of his term of office, or by some direct action on the part of the Senate in the exercise of its constitutional powers. This must be so for the further reason that the declaration in [the statutory provision], that anyone convicted under its provisions shall be incapable of holding any office of honor, trust, or profit 'under the government of the United States,' refers only to offices created by, or existing under the direct authority of, the national government, as organized under the Constitution, and not to offices the appointments to which are made by the states, acting separately, albeit proceeding, in respect of such appointments, under the sanction of that instrument. While the Senate, as a branch of the legislative department, owes its existence to the Constitution, and participates in passing laws that concern the entire country, its members are chosen by state legislatures, and cannot properly be said to hold their places 'under the government of the United States.'

Id. at 369-70. How the Burton Court's ratio decidendi would apply (if at all) to the presidency is less than pellucidly clear. 


\section{A. The Legal Populist}

The legal populist approach is the interpretive position of the person on the street. The populist's position is largely an intuition or feeling. As Baron Devlin explained:

He is not expected to reason about anything and his judgement may be largely a matter of feeling. It is the viewpoint of the man on the streetor to use an archaism familiar to all lawyers-the man in the Clapham omnibus. He might also be called the right-minded man. ${ }^{11}$

I expect our rider on the Clapham omnibus (or to make the analogy more on-point, the American rider on the bus going past the Supreme Court of the United States) - if asked to squarely address Section 2071's meaningwould say:

In everyday language, the presidency is described as an 'office,' and the president is an 'officer.' Similarly, the presidency is not a state or municipal position; rather, it is a national or federal position whose occupant is responsible to the United States, and its people, as a whole. Therefore the presidency can be characterized as "under the United States." Because the presidency is an "office" and because the President works for "the United States," it would seem to follow that the presidency is an "office under the United States" as that language is used in Section 2071. ${ }^{12}$

11 Patrick Devlin, The Enforcement of Morals 15 (1965).

12 Indeed, our bus rider's intuition would not lack some good authority: the Constitution of the United States describes the presidency as an "office," although nowhere expressly describing the presidency as an "office under the United States." See U.S. Const. art. I, § 3, cl. 5 (using the phrase "Office of President of the United States"); id. at art. II, § 1, cl. 5 (same); id. at art. II, § 1, cl. 8 (same); see also Applicability of the Emoluments Clause and the Foreign Gifts and Decorations Act to the President's Receipt of the Nobel Peace Prize, 33 Op. O.L.C., 2009 WL 6365082, at *4 (2009) (Barron, Acting Assistant Att'y Gen.) (announcing that "[t]he President surely 'hold[s] an[] Office of Profit or Trust" (quoting U.S. ConsT. art. I, § 9, cl. 8) (latter two alterations in original)); Steven G. Calabresi, Rebuttal, Does the Incompatibility Clause Apply to the President?, 157 U. PA. L. Rev. PENNumbra 134, 141-45 (2008) (arguing that the Incompatibility Clause, which uses "office under the United States" language, reaches the presidency); Steven G. Calabresi, Closing Statement, A Term of Art or the Artful Reading of Terms?, 157 U. PA. L. Rev. PENNumbra 154, 159 (2008) ("The text [of the Incompatibility Clause] forbids members of Congress from holding 'any Office under the United States.' The presidency is plainly such an office."); John F. Manning, Response, Not Proved: Some Lingering Questions About Legislative Succession to the Presidency, 48 Stan. L. Rev. 141, 146 (1995) (asserting that "[t]he Presidency is surely an 'Office under the United States"'); Saikrishna Bangalore Prakash, Response, Why the Incompatibility Clause Applies to the Office of President, 4 DuKE J. CONST. L. \& PuB. Pol'y 143, 143 (2009) (asserting that "[t]he President occupies an 'Office under the United States" and denominating that position the "conventional wisdom"); Zephyr Teachout, The Anti-Corruption Principle, 94 Cornell L. Rev. 341, 366 (2009) ("Foreign corruption of the Executive was a concern as well, as we saw in the Foreign Gifts Clause [which uses 'office . . . under the United States' language]."); infra note 14 (collecting multiple statements by former Attorney General Mukasey asserting the legal populist position); $c f$. SAIKrishna Bangalore Prakash, IMPERIal From the Beginning: The Constitution of the Original Executive 48 (2015) (asserting that "a president may not simultaneously sit in Congress"); Ah, The Old "Everybody Does It" Defense, Investor's BusiNESS DAILY, Mar. 19, 2015, at A12 ("Not only is there a possible felony in her violations of the Federal Records Act, but the U.S. Criminal Code (18 U.S. Code Section 2071 B) also says the perpetrator 'shall forfeit his office and be disqualified from holding any office under the United States.' Hillary 
For example, Megyn Kelly, a national newscaster stated:

And I refer the audience to 18 U.S. [C]ode, [S]ection 2071-B, look at it. 'Whoever having the custody of any federal record, willfully and unlawfully conceals removes or destroys the same shall be fined or imprisoned or both' and listen-'and shall be disqualified from holding any office under the United States.' If [Hillary Clinton] willfully concealed these emails, not only did she commit a crime, she cannot be president. ${ }^{13}$

Likewise Sean Hannity, another national newscaster, had an exchange on the scope of Section 2071 with Michael Mukasey. Mukasey is a former Attorney General of the United States and also a former Chief Judge of the United States District Court for the Southern District of New York. Hannity and Mukasey stated:

Hannity: Let's go to the third law that we're talking about here. And this would be 18 U.S. [C]ode [\$] 2071. ... I would think that [violating

Clinton could not run for president."); Josh Chafetz, 20th Amendment Trivia, ConLawProf (Nov. 10, 2008, 12:17 PM), http://lists.ucla.edu/cgi-bin/mailman/private/conlawprof/2008-November/033299. $\mathrm{html}$ ("I happen to think that the President is an officer under the United States, but some think otherwise."). But see infra note 74 (discussing Attorney General Mukasey's subsequent retraction in The Washington Post-Volokh Conspiracy).

I have had occasions in the past to express my views in regard to the scope of the Constitution's "office under the United States" language and its variants. See Seth Barrett Tillman, Why Professor Lessig's "Dependence Corruption" Is Not a Founding-Era Concept, 13 ElEction L.J. 336 (2014) (peer reviewed) (arguing that "office under the United States" language, and its close variants, used in the (original) Constitution of 1787-1788, and in contemporaneous instruments, does not reach the presidency); Seth Barrett Tillman, Interpreting Precise Constitutional Text: The Argument for a "New" Interpretation of the Incompatibility Clause, the Removal \& Disqualification Clause, and the Religious Test Clause-A Response to Professor Josh Chafetz's Impeachment \& Assassination, 61 Clev. St. L. Rev. 285 (2013) (same); Seth Barrett Tillman, Why Our Next President May Keep His or Her Senate Seat: A Conjecture on the Constitution's Incompatibility Clause, 4 Duke J. Const. L. \& Pub. Pol'y 107 (2009) (same); Seth Barrett Tillman, Opening Statement, Why President-Elect Obama May Keep His Senate Seat After Assuming the Presidency, 157 U. PA. L. Rev. PENNumBra 134, 135-40 (2008) (same, and Tillman's opening statement); id. at 146-53 (same, and Tillman's closing statement); Seth Barrett Tillman, Member of the House of Representatives and Vice President of the US: Can Paul Ryan Hold Both Positions at the Same Time?, Jurist-Forum, Aug. 23, 2012, http://jurist.org/forum/2012/08/seth-barrett-tillman-vice-presidency.php (same); see also Tillman, supra note 5 (discussing the scope of the Constitution's office-language in the Disqualification Clause); cf., e.g., Seth Barrett Tillman, Letter to the Editor, Oath of Officers, Claremont Review of Books, Summer 2015, at 11 (opining on the temporal scope of the Article VI oath). Compare, e.g., Seth Barrett Tillman, Opening Statement, Citizens United and the Scope of Professor Teachout's Anti-Corruption Principle, 107 Nw. U. L. REv. 399 (2012) (arguing that "office under the United States" language, and its close variants, used in the (original) Constitution of 1787-1788, and in contemporaneous instruments, does not reach the presidency and other elected positions), and Seth Barrett Tillman, Closing Statement, The Original Public Meaning of the Foreign Emoluments Clause: A Reply to Professor Zephyr Teachout, 107 Nw. U. L. Rev. Colloquy 180 (2013) (same), with Zephyr Teachout, Rebuttal, Gifts, Offices, and Corruption, 107 Nw. U. L. Rev. ColloQuy 30 (2012) (suggesting that the Constitution's office language reaches elected positions), and Zephyr Teachout, Closing Statement, Constitutional Purpose and the Anti-Corruption Principle, 108 Nw. U. L. REv. ONLINE 200 (2014) (same).

13 Megyn Kelly \& Shannen Coffin, Did Hillary Clinton knowingly violate the law?, Fox NEws NETwORK (Mar. 18, 2015, 9 PM EST), http://www.foxnews.com/transcript/2015/03/18/did-hillaryclinton-knowingly-violate-law/. 
Section 2071] would mean you can't be the [P]resident of the United States ....

Mukasey: I would think it would mean precisely that, among other things. ${ }^{14}$

Finally, Professor Akhil Amar has stated, without any equivocation or even any acknowledgment of contrary views, that " $[t]$ he presidency is an 'office under the United States." "15 Albeit, Amar was explaining how that phrase is used in the Constitution, not Section 2071.

In each example above, the two national newscasters, the (former) Attorney General, and the academic from Yale Law School-no analysis, no reasoning, and no authority is put forward. This is not surprising because here the basis of the position is a simple text-based intuition. ${ }^{16}$ To sum up, if the legal populists' intuitionist approach is correct, if the meaning of "office under the United States" extends to the presidency, then a conviction under Section 2071 imposes a statutory bar against holding the presidency.

14 Trump on Iran: 'They will know I am not playing games, ' Hannity: Fox News (Aug. 12, 2015, 10 PM ET), http://www.foxnews.com/transcript/2015/08/12/trump-on-iran-will-know-am-not-playing-games. Attorney General Mukasey has made similar statements in other fora. See, e.g., John Heilemann \& Josh Green, Fmr. Attorney General Michael Mukasey Intvd on Blmbg TV, BцoомBERG TV (Aug. 24, 2015, 12:00 AM EST) (Mukasey: "[Section 2071] also carries a permanent disqualification from holding any further office, which is kind of odd. And that - I mean, since she is obviously running for another office, that would present a certain problem." (emphasis added)); Transcript, Morning Joe, MSNBC (Aug. 24, 2015, 6:45:25 AM) ("Mukasey: [I] think the more dangerous part of this from [Hillary Clinton's] standpoint is not so much the placement of the material there [on her server] as wiping the server .... [N] umber one, that's a felony, but that statute makes you unqualified - disqualifies you from holding any further office in the United States and she's running for a further office under the [U]nited [S]tates.") (at 6:47:57 AM), http://goo. gl/na0GM4; see also, e.g., Benghazi, Emails And Family, Investor's Business Daily, Aug. 25, 2015, at A13 ("The case against Clinton picked up Monday when former Attorney General Mike Mukasey said on MSNBC that Clinton has disqualified herself from holding office because she destroyed federal records when she had the server wiped clean."); Emails one Hill of a problem for presidency push, The Daily Telegraph (Austl.), Aug. 26, 2015, at 17 ("Hillary Clinton could find herself disqualified from becoming president if her worst-case legal scenario should come to pass, a former US attorney-general says."); Hillary on the brink, Herald Sun (Austl.), Aug. 26, 2015, at 17 (Mukasey: "[T]hat statute disqualifies you from holding any further office in the United States. And she's running for a further office . . ..”) (available on Nexis); $c f$. David Martosko, Former attorney general says classified email scandal 'disqualifies' Hillary Clinton from serving as president - IF she's prosecuted for breaking federal law, MaIL ONLINE (U.K.) (Aug. 24, 2015, 9:14 PM GMT), http://tinyurl.com/qha6enh (quoting Mukasey's statement on Morning Joe, MSNBC, supra); Jazz Shaw, Former Attorney General: Clinton may have "disqualified herself for elected office, ” Нот AIR (Aug. 24, 2015, 9:21 AM), http://hotair.com/archives/2015/08/24/former-attorney-general-clinton-may-have-disqualified-herself-for-elected-office ("Mukasey went a step further and said that Clinton may have disqualified herself from elected office if the allegations prove to be true."); supra note 12 (quoting Investor's Business Daily article, a newspaper article, asserting the legal populist position). But see infra note 74 (discussing Attorney General Mukasey's subsequent retraction in The Washington Post-Volokh Conspiracy).

15 Amar, THe Law OF the LAND, supra note 10, at 332 n.8; see also Amar \& Amar, supra note 10, at $114-15$.

16 The reader should in no way imagine that my exposition here is sarcastic. Interpretations of legal text that veer far from the intuitions of the person in the street - or, from the intuitions of the legal expert who is immersed in the law-risk losing popular legitimacy. See supra notes $10 \& 15$, and accompanying text (quoting Professors Akhil Amar and Vikram Amar); supra note 12 (collecting other modern academic authority). 


\section{B. The Historical Approach}

Some early American materials cast light on the meaning of "office under the United States." Indeed, we can turn to two separate incidents from President George Washington's first administration to understand the meaning of this somewhat opaque phrase.

\section{President George Washington's Gift from the French Ambassador}

\section{The Constitution's Foreign Emoluments Clause provides:}

$[\mathrm{N}] \mathrm{o}$ Person holding any Office ... under the[] [United States], shall, without the Consent of the Congress, accept of any present, Emolument, Office, or Title, of any kind whatever, from any King, Prince, or foreign State. ${ }^{17}$

Does this provision's office under the United States language apply to the President?

On December 22, 1791, the French ambassador to the United States, Jean-Baptiste, chevalier de Ternant, sent President George Washington a letter stating: "Permit me to present you with a new print of the king of the [F]rench-I shall feel a very great Satisfaction if you will consider that feeble mark of my lively and respectful attachment for your person, as worthy your kind acceptance." 18

President Washington replied the same day. He wrote:

Philadelphia, Decr 22nd 1791.

Dear Sir,

I accept, with great pleasure, the new and elegant print of the King of the French, which you have been so obliging as to send to me this morning as a mark of your attachment to my person. You will believe me, Sir, when I assure you, that I have a grateful and lively sense of the personal respect and friendship expressed in your favor which accompanied the Print, and that I am, with sentiments of sincere esteem and regard, Dear Sir, your most obedt Servt

Go: Washington. ${ }^{19}$

17 U.S. Const. art. I, $\S 9$, cl. 8 ("No Title of Nobility shall be granted by the United States: And no Person holding any Office of Profit or Trust under them, shall, without the Consent of the Congress, accept of any present, Emolument, Office, or Title, of any kind whatever, from any King, Prince, or foreign State.").

18 Letter from Ambassador Ternant to George Washington (Dec. 22, 1791), in 9 THE PAPERS OF George Washington 306, 306 n.1 (Mark A. Mastromarino \& Jack D. Warren, Jr. eds., 2000) (emphasis added).

19 Letter from George Washington to Ambassador Ternant (Dec. 22, 1791), in 9 THE PAPERS OF George Washington, id. at 306 (emphasis added) (editors' footnote omitted). 
Washington accepted the ambassador's gift (the print and its frame), he $k e p t$ the gift, and he never asked for congressional consent to accept or to keep the gift. This gift was not one of de minimis value, ${ }^{20}$ nor was it a gift from a close personal friend or relative of Washington's. It was an official or diplomatic gift from a foreign ambassador to our head of state. ${ }^{21}$ This incident suggests that President Washington was not an Officer . . under the United States, and that he did not conceive of his position as one.

Is it possible that President Washington erred in regard to accepting the French ambassador's gift, but failing to ask for congressional consent? Evidence arising in connection with the Washington administration is generally considered superior to that of later administrations. ${ }^{22}$ Why? First, Washington's administration was contemporaneous with the Constitution's ratification. ${ }^{23}$ Second, the

20 See William Adair, George Washington's Frames: A Study in Contrasts, Picture Framing Mag., June 1992, at 34, 34-35; Wendy Wick Reaves, The Prints, AntiQues, Feb. 1989, at 502, 502-03; Louis Seize, Roi de Français, Restaurateur de la Liberté, 1790, GEORge Washington’s Mount Vernon Estate, Museum \& Gardens, http://www.mountvernon.org/research-collections/collections-holdings/browse-the-museum-collections/object/w-767a-b/ (last visited Dec. 1, 2015).

21 See William B. Adair, A Masterpiece of Artisanship, Picture Framing Mag., Aug. 2010, at 28, 28 (describing the print and frame as "an official diplomatic gift"); id. at 32 ("The history of this Royal Palace frame is clear, having been an official gift to Washington."). But see AmAR, BIOGRAPHY, supra note 10, at 182 ("Article I, section 9 barred all federal officers, from the president on down, from accepting any 'present' or 'Emolument' of 'any kind whatever' from a foreign government without special congressional consent."). Interestingly, Professor Amar does not discuss this gift or, indeed, any of the gifts President Washington received from foreign governments. See Gifts of State, NaT'L ARChIVES, http://www.archives.gov/exhibits/tokens_and_ treasures/gifts_of_state.html (last visited Dec. 1, 2015) (“[I]ndeed, every President since George Washington has received gifts of state.").

22 See, e.g., Akhil Reed Amar, America's Unwritten Constitution: The Precedents and PrinciPLES We Live By 309 (2012) ("Over the centuries, the constitutional understandings that crystallized during the Washington administration have enjoyed special authority on a wide range of issues . . . "); $c f$., e.g., Steven G. Calabresi \& Christopher S. Yoo, The Unitary Executive: Presidential Power from Washington to Bush 420 (2008) ("The precedent set by Washington [in regard to directing subordinates] was followed by all his successors.").

23 Nine states were required for ratification. See U.S. Const. art. VII ("The Ratification of the Conventions of nine States, shall be sufficient for the Establishment of this Constitution between the States so ratifying the Same."); Owings v. Speed, 18 U.S. 420, 423 (1820) (Marshall, C.J.) ("It is apparent that the Government did not commence on the Constitution being ratified by the ninth State; for these ratifications were to be reported to [the Articles] Congress, whose continuing existence was recognised by the Convention, and who were requested to continue to exercise their powers for the purpose of bringing the new government into operation. In fact, [the Articles] Congress did continue to act as a government until it dissolved on the first of November, by the successive disappearance of its members. It existed potentially until the $2 \mathrm{~d}$ of March, the day preceding that on which the members of the new Congress were directed to assemble."). The ninth state-New Hampshire - ratified on June 21, 1788. See Gary Lawson \& Guy Seidman, When Did the Constitution Become Law?, 77 Notre Dame L. Rev. 1, 1 (2001). Subsequently, two more states-Virginia (on June 25, 1788) and New York (on July 26, 1788) - ratified prior to the first meeting of the First Congress under the Constitution. See Gregory E. Maggs, A Concise Guide to the Federalist Papers as a Source of the Original Meaning of the United States Constitution, 87 B.U. L. Rev. 801, 826 (2007). The First Congress was scheduled to meet on March 4, 1789, but it did not have a quorum until April 6, 1789. See Seth Barrett Tillman, The Federalist Papers as Reliable Historical Source Material for Constitutional Interpretation, 105 W. VA. L. REV. 601, 604 \& n.12 (2003). It was the First Congress which counted the electors' votes and gave notice on April 6, 1789 to Washington and Adams that they had been elected President and Vice President. See 1 Annals of Cong. 16-18 (1789) (Joseph Gales ed., 1834). Finally, the last two states of the original thirteen states - North Carolina (on November 21, 1789 ) and Rhode Island (on May 29, 1790) — ratified during President Washington's first term. See Tillman, supra at 604 \& nn. 13 \& 14. See generally Vasan Kesavan, When Did the Articles of Con- 
President was a Framer ${ }^{24}$ and his cabinet (and administration) contained other prominent Framers ${ }^{25}$ and ratifiers. ${ }^{26}$ Indeed, between the President and his nine

federation Cease To Be Law?, 78 Notre Dame L. Rev. 35 (2002); Gary Lawson \& Guy Seidman, The First "Establishment" Clause: Article VII and the Post-Constitutional Confederation, 78 Notre DAME L. ReV. 83 (2002).

24 George Washington, a Virginia delegate, attended the Philadelphia Convention which drafted the Constitution. See Major William Jackson, secretary, Journal of the Convention, in 1 THE RECORDS OF THE Federal Convention of 1787, at 1-2 (Max Farrand ed., 1911) (indicating that, on May 25, 1787, when a quorum of the States was first formed, Washington was in attendance, and also that Washington was elected to the chair, i.e., President of the Convention).

25 First, Alexander Hamilton, a New York delegate, attended the Philadelphia Convention. See 1 id. at 1 (indicating that Hamilton was in attendance on May 25, 1787). Hamilton was President Washington's first Secretary of the Treasury. See Susan Low Bloch, The Early Role of the Attorney General in our Constitutional Scheme: In the Beginning there was Pragmatism, 1989 Duke L.J. 561, 577 n.54.

Second, Edmund Randolph, a Virginia delegate, attended the Philadelphia Convention. See 1 THE Records of the Federal Convention, supra note 24, at 1 (indicating that Randolph was in attendance on May 25, 1787). Randolph was President Washington's first Attorney General. See Bloch, supra at 564.

Third, James McHenry, a Maryland delegate, attended the Philadelphia Convention. See 1 THE REcords of the Federal Convention, supra note 24, at 7 (indicating that McHenry was in attendance on May 28, 1787). McHenry succeeded Timothy Pickering; thus McHenry became President Washington's third Secretary of War. See David F. Forte, Marbury's Travail: Federalist Politics and William Marbury's Appointment as Justice of the Peace, 45 Cатн. U. L. Rev. 349, 370-71 (1996).

Fourth and finally, Gouverneur Morris, a Pennsylvania delegate, attended the Philadelphia Convention. See Morris, Gouverneur (1752-1816), Biographical Directory of the United States Congress, http://bioguide.congress.gov/scripts/biodisplay.pl?index=M000976 (last visited Feb. 11, 2016). President Washington appointed Morris Minister Plenipotentiary for the United States, at Paris. See id. This position, although not in the cabinet, was tied as the second highest paid position in the government: only the President had a higher salary. See Alexander Hamilton, List of Civil Officers of the United States, Except Judges, with their Emoluments, for the Year Ending October 1, 1792 (Feb. 26, 1793), in 1 American State Papers: Miscellaneous 57, 57-68 (Walter Lowrie \& Walter S. Franklin eds., Washington, Gales and Seaton 1834) (listing compensation of government officials, including the President, who made $\$ 25,000$ per year, and Morris and Pinckney, who each made $\$ 9,000$ per year, and also received $\$ 9,000$ for “outfit”), http://tinyurl.com/z6h9u23. (A reproduction of Hamilton's original document appears in The Papers of Alexander Hamilton. See infra note 33.) By contrast, the Vice President of the United States made $\$ 5,000$ per year, and the Chief Justice made $\$ 4,000$ per year. Id.; History of the Federal Judiciary: Judicial Salaries, Federal Judicial Center, http://www.fjc.gov/history/home. nsf/page/js 1.html (last visited Feb. 11, 2016).

26 First, Alexander Hamilton was a ratifier: he attended New York's state convention which ratified the Constitution. See 2 The Debates in the Several State Conventions on the Adoption of the Federal Constitution as Recommended by the General Convention at Philadelphia in 1787, at 205-06, 216, 230-39 (Jonathan Elliot ed., Washington, n.p. 2d ed. 1836) (vol. 1, 1st ed. 1827) (indicating that Hamilton had been elected to the New York convention, which convened on June 17, 1788, and that he spoke on June 20, 1788); supra note 25 (describing Hamilton's cabinet career).

Second, Edmund Randolph was a ratifier: he attended Virginia's state convention which ratified the Constitution. See 3 The Debates in the Several State Conventions (vol. 2, 1st ed. 1828), supra at 1 (indicating that Randolph was in attendance on June 2,1788, when the Virginia convention convened); supra note 25 (describing Randolph's cabinet career).

Third, Timothy Pickering was a ratifier: he attended Pennsylvania's state convention which ratified the Constitution. See 2 The Debates in the Several State Conventions (vol. 3, 1st ed. 1830), supra at 416-17 (indicating that Pickering had been elected to the Pennsylvania convention); 1 id. at 319-20 (indicating that Pickering had signed the document recording the Pennsylvania convention's ratification). Pickering succeeded Henry Knox; thus Pickering became President Washington's second Secretary of War. See Louis Fisher, Lost Constitutional Moorings: Recovering the War Power, 81 IND. L.J. 1199, 1207 (2005).

Fourth, Joseph Habersham was a ratifier: he attended Georgia's state convention which ratified the Constitution. See 1 The Debates in the Several State Conventions, supra at 323-24 (indicat- 
cabinet members (over the course of two terms), half of the group were either Framers or ratifiers or both. ${ }^{27}$ Third, the President saw himself above party or faction; indeed, active partisan federal electoral politics did not arise until after Washington announced that he would not run for a third term. ${ }^{28}$ Fourth, Washington both valued his reputation for probity and acted under the assumption that his conduct was closely monitored by political opponents and opportun-

ing that Habersham had signed the document recording the Georgia convention's ratification). Habersham succeeded Pickering; thus Habersham became President Washington's third Postmaster General. See Noble E. Cunningham, The Process of Government under Jefferson 18 (1978) (noting that "Habersham had been appointed Postmaster General by Washington in 1795"). During Washington's administration and the early Federalist Era, Postmaster General was a senior post, but it was not part of the President's cabinet. $C f$. id. at 87 (indicating that as late as Jefferson's administration, the Postmaster General was not part of the cabinet).

Fifth and finally, Thomas Pinckney was a ratifier: he attended South Carolina's state convention which ratified the Constitution; indeed, he was president of the state convention. See Pinckney, Thomas (1750-1828), Biographical Directory of the United States Congress, http://bioguide. congress.gov/scripts/biodisplay.pl?index=P000357 (last visited Feb. 11, 2016). President Washington appointed Pinckney Minister Plenipotentiary for the United States, at London. See id. This position, although not in the cabinet, was tied as the second highest paid position in the government: only the President had a higher salary. See Hamilton, List of Civil Officers of the United States, supra note 25, at 57-68 (listing compensation of government officials, including the President, who made $\$ 25,000$ per year, and Pinckney and Morris, who each made $\$ 9,000$ per year, and also received \$9,000 for "outfit"), http://tinyurl.com/z6h9u23; see supra note 25 (reporting the Vice President's and Chief Justice's salaries).

27 See Cabinet Members, George Washington's Mount Vernon, http://www.mountvernon.org/ digital-encyclopedia/article/cabinet-members/ (last visited Feb. 12, 2016) (listing Jefferson, Randolph, and Pickering as President Washington's Secretaries of the State; listing Hamilton and Wolcott as Washington's Secretaries of the Treasury; listing Knox, Pickering, and McHenry as Washington's Secretaries of War; and listing Randolph, Bradford, and Charles Lee as Washington's Attorneys General). Thus, Washington's nine cabinet members included: (i) Jefferson, (ii) Randolph, (iii) Pickering, (iv) Hamilton, (v) Wolcott, (vi) Knox, (vii) McHenry, (viii) Bradford, and (ix) Charles Lee. Washington was a Framer (from Virginia), and four of his nine cabinet members were Framers or ratifiers or both, including: (i) Hamilton-Framer and ratifier (from New York); (ii) Randolph-Framer and ratifier (from Virginia); (iii) McHenry-Framer (from Maryland); and (iv) Pickering-ratifier (from Pennsylvania). See supra notes 24-26. Thus, between Washington and his nine cabinet members, five of ten were either Framers or ratifiers or both. (I am not counting John Jay, who, prior to Jefferson, was Acting Secretary of State, as holdover Secretary of Foreign Affairs from the outgoing Confederation government.)

28 See, e.g., Stanley Elkins \& Eric McKitrick, The Age of Federalism: The Early American RePUBLIC, 1788-1800, at 495 (1993) ("[T]he role Washington had marked out for himself - that of a chief magistrate resolutely above all party and faction - was one which by the end of his administration he saw himself less and less able to protect. The unity which he, as the first head of a fragile republic exposed to all the broils of world conflict, had worked so painfully to construct was being threatened by irresponsible partisans in the nation's midst."); id. at 496-97 (same); Bruce Ackerman \& David Fontana, Thomas Jefferson Counts Himself into the Presidency, 90 VA. L. Rev. 551, 568-69 (2004) ("Washington's Farewell Address nicely framed the transition to this new [politically partisan] order. On the one hand, it was a great act of nonpartisan statesmanship - in refusing a third term in office, Washington established a precedent against the pernicious tendency toward presidencies-for-life. On the other hand, partisan politics provided a backdrop to Washington's grave farewell. He postponed his announcement until September 17, 1796. This put the Republicans at a serious disadvantage in the presidential election campaign, as Jefferson and his supporters were not prepared to contest Washington's decision to continue in office. Nevertheless, the Republicans almost managed to defeat John Adams, Washington's Vice-President and a man devoted to Washington's non-party ideal, who was now obliged to make his way in the ascendant world of party politics." (footnotes omitted)). 
ists. ${ }^{29}$ Fifth, Washington understood that his personal and his administration's conduct were precedent-setting in regard not only to significant deeds, but even in regard to what might appear to be minor events and conduct. ${ }^{30}$ Indeed, the dominant view is that Washington's conduct deserves special deference in regard to both "foreign affairs" ${ }_{11}$ and "presidential etiquette." 32 Both of these latter considerations apply to the facts, circumstances, and legal issues surrounding President Washington's accepting the French ambassador's gift. It follows then that if Washington did not err, then the President is not encompassed by the Foreign Emolument Clause's “office . . . under the United States” language. It would seem to follow that if President Washington was not an "office[r] ... under the United States" for the purposes of the Foreign Emoluments Clause, then president-elect Clinton (should she be elected) would not be an "office[r] under the United States" under Section 2071.

\section{Secretary Hamilton's List}

There is a second precedent from the Washington administration. In 1792, the Senate ordered Secretary of the Treasury Alexander Hamilton to draft a financial statement listing all persons holding "office . . . under the United States" and their salaries. Hamilton took more than nine months to draft a response. Hamilton's response, in 1793, was some ninety manuscript-sized pages. In it, he included personnel in each of the three branches of the federal government. But Hamilton did not include the President, Vice President, Senators, or Representatives. In other words, Hamilton included only those holding office via appointment, but not anyone holding a constitutionally-mandated or elected federal position. ${ }^{33}$ If the presidency was not an "office ... under the United

29 See, e.g., Letter from George Washington to Bushrod Washington (July 27, 1789), in 30 THE Papers of George Washington 366, 366 (John C. Fitzpatrick ed., 1939) ("You cannot doubt my wishes to see you appointed to any office of honor or emolument in the new government .... My political conduct in nominations . . . must be exceedingly circumspect and proof against just criticism, for the Eyes of Argus are upon me, and no slip will pass unnoticed that can be improved into a supposed partiality for friends or relatives.").

30 See Letter from President George Washington to Vice President John Adams (May 17, 1789), in 8 The Works of John Adams: Second President of the United States 489, 490 (Charles Francis Adams ed., Boston, Little, Brown and Co. 1853) ("Many things, which appear of little importance in themselves and at the beginning, may have great and durable consequences from their having been established at the commencement of a new general government."); 2 THE LifE OF GENERAL Washington: First President of the United States 189, 190-92 (Rev. C. W. Upham ed., London, National Illustrated Library 1861) (reporting that the same basic letter which was sent to Adams, was also sent to Madison on May 12, 1789, and that a similar letter was also sent to Jay and Hamilton); see also Letter from George Washington to James Madison (May 5, 1789), in 30 The Writings of George Washington from the Original Manuscript Sources 1745-1799, at 310-11 (John C. Fitzpatrick ed., 1939) ("As the first of every thing, in our situation will serve to establish a Precedent, it is devoutly wished on my part, that these precedents may be fixed on true principles."). See generally AMAR, supra note 22, at 564 n.2 (same).

31 Id. at 309-10.

32 Id.

33 See Report on the Salaries, Fees, and Emoluments of Persons Holding Civil Office Under the United States (Feb. 26, 1793), in 14 The Papers of Alexander Hamilton: February 1793-June 1793, at 157, 157-59 (Harold C. Syrett \& Jacob E. Cooke eds., 1969), http://works.bepress.com/seth_barrett_tillman/203/3/download; supra note 25 (reporting a nearly identical document in American 
States" for the purposes of Hamilton's list, it would seem to follow that the presidency is not an "office under the United States" as that phrase is used in other legal documents and instruments, including Section 2071.

\section{Post-Civil War Scholarship}

Later commentators seem to agree. McKnight, a late nineteenth-century commentator, discussing how "office" language was used in the Constitution, stated: "It is obvious that ... the President is not regarded as 'an officer of, or under, the United States,' but as one branch of 'the Government." '34 Likewise, Anne Twomey, a modern commentator, discussing how "office under the Crown" is used in Australian law, stated: "As [the public position at issue] is an elective office, and not generally subject to the direction or supervision of the government, one would assume that it is not an office held 'under the Crown'." 35

The origins of Section 2071's disqualification-related "office under the United States" language go back to the modern statute's 1853 predecessor. ${ }^{36}$ As explained, we have eighteenth-century precedents from President Washington and his administration, late nineteenth-century scholarly authority, and modern scholarly authority, domestic and foreign, indicating that this "office under the United States" language (or closely similar language) does not reach elected positions, such as the presidency. This would seem to indicate that the 1853 statute's “office under the United States" language and its modern successor, Section 2071, do not reach the presidency.

Although this historical approach has a certain attractiveness, it is hardly decisive. Our goal here is not to understand how "office . . . un-

State Papers); see also 1 Journal of the Senate of the United States of America, Being the First Session of the Second Congress: Begun and held at the City of Philadelphia, October 24, 1791, and In the Sixteenth Year of the IndePendence of the SAid States 441 (1792) (Washington, Gales \& Seaton 1820) (reporting May 7, 1792 Senate order, which stated: "That the Secretary of the Treasury do lay before the Senate, at the next session of Congress, a statement of the salaries, fees, and emoluments, for one year, ending the first day of October next, to be stated quarterly, of every person holding any civil office or employment under the United States ...."). It should go without saying that Hamilton's list encompassed no (appointed or elected) state positions.

34 David A. McKnight, The Electoral System of the United States 346 (Philadelphia, J.B. Lippincott \& Co. 1878); $c f$. Suspension of the Privilege of the Writ of Habeas Corpus, 10 Op. Att'y Gen. 74, 79 (1861) (Bates, A.G.) ("The President is a department of the government; and ... the only department which consists of a single man ....").

35 Anne Twomey, The Constitution of New South Wales 438 (2004). See generally Luke Beck, When Is an Office or Public Trust 'Under the Commonwealth' for the Purposes of the Religious Tests Clause of the Australian Constitution?, 41(1) Monash U. L. Rev. 17 (2015) (peer reviewed); Luke Beck, The Constitutional Prohibition on Religious Tests, 35 Melbourne U. L. Rev. 323 (2011) (peer reviewed); Luke Beck, Note, Williams v Commonwealth, School Chaplains and the Religious Tests Clause of the Constitution, 38(3) MonASH U. L. Rev. 271 (2012) (peer reviewed). The Australian Constitution's Religious Test Clause, including its "office" language, is modelled on its predecessor in the United States Constitution. Compare Australian Constitution s 116 (" $[\mathrm{N}]$ o religious test shall be required as a qualification for any office or public trust under the Commonwealth."), with U.S. ConST. art. VI, cl. 3 (“[N]o religious Test shall ever be required as a Qualification to any Office or public Trust under the United States.").

36 See An Act to Prevent Frauds Upon the Treasury of the United States, 32d Cong., 2d Sess., ch. 81, $\S 5$, 10 Stat. 170, 170-71 (1853) (imposing a disqualification in regard to holding any "office under . . . the United States"); Note, Historical Writings: The Independent Value of Possession, 67 YaLE L.J. 151, 154 n.19 (1957) (noting the 1853 origins of Section 2071). 
der the United States" was used in 1791 (per Washington), in 1793 (per Hamilton), or in 1878 (per McKnight), or thereafter. Nor is our goal to understand how this phrase (or closely similar statutory terminology) was understood in other contexts, domestic and foreign, unrelated to Section 2071. Rather, our goal "is to construe the language [of the statute] so as to give effect to the intent of Congress." ${ }^{37}$ Thus, this historical argument is convincing to the extent we can be confident that Congress in 1853 was making use of standard legal jargon, whose meaning was: (i) static since Washington's and Hamilton's day; (ii) singular and undisputed; and (iii) shared widely at the time Congress enacted this provision.

\section{Presumptions of Statutory Interpretation}

Recognizing the ambiguity and difficulty in regard to determining Congress' intent in regard to Section 2071's “office under the United States” language, this approach turns to general presumptions, principles, or canons of statutory interpretation.

\section{General "Office" Language does not Reach the Presidency}

It is an accepted principle of federal statutory construction that general language in a statute, such as "agency," which does not explicitly refer to the presidency amounts to "textual silence." ${ }^{38}$ Such "textual silence is not enough to subject the presidency to the provisions of" 39 a statute. This principle of statutory construction is primarily rooted in two policy concerns: "separation of powers and the unique constitutional position of the President." 40

It is not clear that these concerns are at play here. For example, if in the future former Secretary Clinton were elected to the presidency, and if prior to the start of her four-year term she were convicted under Section 2071 , then, arguably, such a conviction would prevent Clinton, the president-elect, from becoming President in the first instance, and presumably, someone else (i.e., the vice president elect) would succeed to the presidency. Such a successor, as a formal legal matter, would be free to exercise all the powers and prerogatives of the presidency. However, it is possible (perhaps likely) that a successor in such circumstances would not enjoy the broad democratic mandate of a president-elect: as a practical matter, such a successor might be unable to wield the full powers of office.

On the other hand, the Department of Justice's Office of Legal Counsel has argued that this principle of statutory construction applies where the statute's application impinges on the "President's constitutional

\footnotetext{
37 United States v. Am. Trucking Ass'ns, 310 U.S. 534, 542 (1940) (Reed, J.).

38 Franklin v. Massachusetts, 505 U.S. 788, 800 (1992) (O'Connor, J.); cf. Nixon v. Fitzgerald, 457 U.S. 731, 748 \& n.27 (1982) (Powell, J.).

39 Franklin, 505 U.S. at $800-01$.

40 Id. at 800 .
} 
prerogatives." 41 One might suggest that, notwithstanding the availability of a successor, a statute which prevents a president-elect from becoming President, and therefore, which prevents such a person from exercising any presidential powers, is one which impinges on the "president's constitutional prerogatives." If this syllogism is substantially correct, it follows that Section 2071's general "office under the United States" language does not apply to the presidency.

Furthermore, this principle of statutory construction-i.e., that general language in a statute does not cover the presidency-has been understood to apply even where the stated policy concerns are not at play. ${ }^{42}$ For example, former President Eisenhower died on March 28, 1969. President Nixon planned to close federal government offices on March 31, 1969 in memory of his dead predecessor. However, 5 United States Code Section 6105 stated: "An Executive department may not be closed as a mark to the memory of a deceased former official of the United States." 43

The President's staff sought advice from the Office of Legal Counsel. After an examination of the provision's text and legislative history, thenAssistant Attorney General William H. Rehnquist (later Chief Justice of the United States) concluded:

[S]tatutes which refer to 'officers' or 'officials' of the United States are construed not to include the President unless there is a specific indication that Congress intended to cover the Chief Executive. ${ }^{44}$

I have found no evidence of any such "specific indication" in reported congressional debate on the 1853 statute ${ }^{45}$ indeed, I found no congressional debate in any way addressing the statute's "office under the United States" language. Furthermore, Rehnquist opined that this principle of statutory interpretation is "particularly applicable" where the statute is "obscure." "46 All this is some reason to conclude that Section 2071's general "office under the United States" language does not cover the presidency.

${ }_{41}$ Memorandum for the General Counsels of the Federal Government, 20 Op. O.L.C. 124, 1996 WL 876050, at *34 (1996) (Dellinger, A.G.). Consider a slightly different context. If after she were to win the November 2016 popular general election, Clinton were prosecuted under Section 2071 by the outgoing administration, and afterwards sworn into office in January 2017, and subsequently convicted, then Section 2071's disqualification provision would not keep her from becoming President, but would instead (arguably) remove her from office. Although such a result might not impinge on the "presidency's constitutional prerogatives" (as long as a successor were available), such a result does impinge on the disqualified former "president's constitutional prerogatives."

42 See Neil Kinkopf, Executive Privilege: The Clinton Administration in the Courts, 8 WM. \& MARY BiLl RTs. J. 631, 644 n.94 (2000).

$43 \quad 5$ U.S.C. $\$ 6105(1966)$.

44 Memorandum from William H. Rehnquist, Assistant Attorney General, for the Honorable Egil Krogh, Staff Assistant to the Counsel to the President, Office of Legal Counsel, Re: Closing of Government Offices in Memory of Former President Eisenhower 3 (Apr. 1, 1969), http://works. bepress.com/seth_barrett_tillman/569/1/download.

45 See Cong. Globe, 32d Cong., 1st Sess. 387, 391-92 (1853) (reporting Senate debate, second Senate reading, and Senate passage of Frauds on the Treasury Bill on January 25, 1853); see also id. Appendix at 64-67 (reporting A. Johnson's speech on the Bill in the House); id. Appendix at 67-71 (reporting E.B. Olds' speech on the Bill in the House).

46 Memorandum from William H. Rehnquist, supra note 44, at 3. 


\section{Interpretations of Statutory Language Restricting the Scope of Demo- cratic Choice are not Favored}

Another well-settled canon of statutory construction-the democracy canon-is that statutory and constitutional language limiting eligibility to office is interpreted narrowly. As Corpus Juris Secundum, a leading treatise, explains:

Statutes limiting the right of a person to hold office are to be given a liberal construction in favor of those seeking to hold office in order that the public may have the benefit of choice from all those who are in fact and in law qualified. Ambiguities should be resolved in favor of eligibility to office, and constitutional and statutory provisions which restrict the right to hold public office should be strictly construed against ineligibility. ${ }^{47}$

Because Section 2071's general “office under the United States” language does not explicitly refer to the presidency but does limit candidate eligibility and, in effect, voter rights, this provision should not be interpreted as applying to the presidency.

4767 C.J.S. Officers and Public Employees: Construction and operation of constitutional and statutory provisions, generally $\S 23$ (2015) (footnotes omitted); see also 62 C.J.S. Municipal Corporations $\S 273$ (2011) (“[A]n appointed or elected person should not be prevented from taking office unless clearly ineligible."); Richard L. Hasen, The Democracy Canon, 62 Stan. L. Rev. 69 (2009) (coining the phrase - the "democracy canon"- and developing the concept); Richard L. Hasen, Ted Cruz is Fit for Office, At Least Under the Constitution, NAT. L.J., Jan. 25, 2016, http://tinyurl. $\mathrm{com} / \mathrm{h} 57 \mathrm{ae} 5 \mathrm{r}$ ("The democracy canon counsels that in ambiguous cases of interpretation, read the questionable provision to give voters a choice and to count their votes. . . . But when in doubt, in cases like Cruz's, liberals should emphatically reject any argument that he is ineligible to run for president. There's a constitutional path to say he is eligible, and a contrary interpretation deprives voters of meaningful choice."); Tillman, supra note 5, 108-11 (expounding on the "democracy canon"); Seth Barrett Tillman, A Different Take on Natural Born, The Originalism Blog (Jan. 18, 2016, 6:59 AM), http://tinyurl.com/j8d9hqp; $c f$. Thomas Falconer \& Edward H. Fitzherbert, Cases of Controverted Elections, Determined in Committees of the House of Commons, in the Second Parliament of the Reign of Queen Victoria 587 (Saunders \& Benning 1839) (reproducing committee debate from disputed Galway election of 1838, where Mr. Austin (counsel for the sitting member who prevailed) stated: "In all cases respecting eligibility, eligibility is to be aided, and ineligibility ought to be strictly proved. Severe penalties are imposed by the acts of parliament creating disqualification, and they are not favoured."). Compare Richard L. Hasen, The Benefits of the Democracy Canon and the Virtues of Simplicity: A Reply to Professor Elmendorf, 95 CoRnell L. Rev. 1173, 1173 (2010) ("Though the name 'Democracy Canon' is new, the Canon itself has a long and distinguished pedigree."), with Christopher S. Elmendorf, Refining the Democracy Canon, 95 Cornell L. Rev. 1051, 1056-63 (2010) (discussing the costs of the democracy canon). See generally Edward B. Foley, Implications for Hasen's “Democracy Canon" Thesis, Report to the American Law Institute, Principles of Election Law: Resolution of Election Disputes (Apr. 16, 2012); Chad Flanders, Election Law Behind a Veil of Ignorance, 64 FLA. L. Rev. 1369 (2012); Chad Flanders, More on Veils: Reply to Levitt and Muller, 64 Fla. L. Rev. F. 76 (2012); Justin Levitt, You're Gonna need a Thicker Veil, 64 Fla. L. REv. F. 59 (2013); Derek T. Muller, Disfavored Candidates and the Democracy Canon, 64 Fla. L. Rev. F. 53 (2013). 


\section{If the Statute Reaches the Presidency, is it Constitutional?}

If a court decides that Section 2071 reaches the presidency, it will then turn to the provision's constitutionality. The issue here is one of power: may Congress by statute impose qualifications for the presidency beyond those already in the Constitution's text?

\section{A. Judicial Authority}

In 1966, Adam Clayton Powell, Jr. was elected to a twelfth consecutive term in the United States House of Representatives. Because of allegations of corruption, when the new Congress met in 1967, Powell was not sworn in with the other members-elect. Thereafter, a House committee produced a report which stated that Powell had, prior to the first meeting of the new Congress, wrongfully diverted House funds to himself and others. The House voted to exclude Powell and declared his seat vacant. Powell sued both to regain his seat and for lost salary. In Powell v. McCormack, ${ }^{48}$ decided in 1969, the Supreme Court held that the House's refusal to seat Powell-his exclusion-was unconstitutional. ${ }^{49}$ In other words, the House can only exclude a member-elect based on qualifications expressly stated in the Constitution: e.g., age, years of citizenship, and inhabitancy. ${ }^{50}$ Allegations of corruption, even if proven, will not do. Thus, notwithstanding the Constitution's textually demonstrable commitment granting the House authority (if not exclusive authority) to judge its members' qualifications, ${ }^{51}$ the House's excluding a member-elect for any other reason is unconstitutional. Powell's result was hardly surprising: Alexander Hamilton, prior to ratification of the Constitu-

48395 U.S. 486 (1969) (Warren, C.J.); see also U.S. Term Limits, Inc. v. Thornton, 514 U.S. 779 (1995) (Stevens, J.) (precluding the States from adding to the qualifications for House and Senate membership).

49 Powell was only awarded a declaratory judgment because the congressional term for which he had been wrongfully excluded had already ended by the time the Supreme Court reached its decision. See Powell, 395 U.S. at 550. The declaratory judgment permitted Powell to seek backpay from the lower courts on remand, but only against non-elected House officers, i.e., the Clerk, Sergeant-at-Arms, and Doorkeeper, and not against the Speaker or any members. Judicial review of single-house action in regard to qualifications and related contexts can rarely be timely, and as Powell illustrates, even if available, it is not meaningful. See The Federalist No. 53, supra note 5, at 293-94 (James Madison-but authorship is disputed) ("[I]n single states where they are large and hold but one legislative session in the year, that spurious elections cannot be investigated [by a legislative chamber] and annulled in time for the decision to have its due effect. ... Were elections for the federal legislature to be annual, this practice might become a very serious abuse, particularly in the more distant states.").

$50 \quad$ See supra note 5 (collecting constitutional provisions).

51 See U.S. Const. art. I, $\S 5$, cl. 1 ("Each House shall be the Judge of the Elections, Returns and Qualifications of its own Members ...."). 
tion, took this position in The Federalist, ${ }^{52}$ as did other prominent early postratification commentators, such as Justice Joseph Story. ${ }^{53}$

Powell and its progeny ${ }^{54}$ have come to stand for the proposition that the Constitution's express textual qualifications in Article I for membership in the House and Senate are exclusive. Moreover, the rationale of Powelli.e., the primacy of the Constitution's express provisions setting fixed textual qualifications-would equally apply to the eligibility provisions for the presidency in Article II. ${ }^{55}$ Indeed, this extension of Powell appears uncontroversial. For example, in dicta, Chief Judge Posner explained:

The democratic presumption is that any adult member of the polity ... is eligible to run for office.... The requirement in the U.S. Constitution that the President be at least 35 years old and Senators at least 30 is unusual and reflects the felt importance of mature judgment to the effective discharge of the duties of these important offices; nor, as the cases we have just cited hold, may Congress or the states supplement these requirements. ${ }^{56}$

Federal district courts, i.e., trial courts, including those outside of Chief Judge Posner's United States Court of Appeals for the Seventh Circuit, ${ }^{57}$ and

52 See The Federalist No. 60, supra note 5, at 326 (Alexander Hamilton) ("The qualifications of the persons who may choose or be chosen, as has been remarked upon other occasions, are defined and fixed in the Constitution, and are unalterable by the legislature."); see also THE FEDERALIST No. 52, supra note 5, at 286 (James Madison-but authorship is disputed) (explaining that House qualifications were "regulated" by the "[C]onvention" which framed the Constitution).

53 See 2 Joseph Story, Commentaries on the Constitution of the United States $§ 624$ (Boston, Hilliard, Gray and Company 1833) ("It would seem but fair reasoning upon the plainest principles of interpretation, that when the constitution established certain qualifications, as necessary for office, it meant to exclude all others, as prerequisites."). Albeit, Story was rejecting the power of the States to add qualifications in regard to House and Senate membership.

54 See supra note 48 (citing U.S. Term Limits, Inc.).

55 See supra note 5 (collecting the primary qualifications-related constitutional provisions for elected federal positions, including the presidency).

56 Herman v. Local 1011, United Steelworkers of Am., AFL-CIO, CLC, 207 F.3d 924, 925 (7th Cir. 2000) (Posner, C.J.) (citing Powell and U.S. Term Limits, Inc.).

57 These courts include federal district courts in the United States Courts of Appeals for the First, Third, Fifth, and Sixth Circuits. See, e.g., Liberty Legal Found. v. Nat'l Democratic Party of USA, Inc., 868 F. Supp. 2d 734, 741 (W.D. Tenn. 2012) (Anderson, J.) ("Article II of the Constitution . . . is the exclusive source for the qualifications for the Presidency . . .."); United States v. Caron, 941 F. Supp. 238, 254-55 (D. Mass. 1996) (Young, J.) ("[T]he Constitution is the sole source of eligibility for President of the United States and it does not preclude felons."); see also Nat'l Comm. of the U.S. Taxpayers Party v. Garza, 924 F. Supp. 71, 75-76 (W.D. Tex. 1996) (Nowlin, J.) (adjudicating dispute about qualifications and access to the presidential ballot under the rubric of U.S. Term Limits, Inc.); Gordon v. Sec'y of State of N.J., 460 F. Supp. 1026, 1027 (D.N.J. 1978) (Biunno, J.) ("As a consequence, whether in jail or not, nothing prevented Gordon from seeking to gain the votes of enough electors to have been elected President of the United States. ... Eugene V. Debs ran for President four times and was a candidate while in jail. Gordon was free to do the same." (footnote omitted)); cf., e.g., Muller, supra note 5, at 571 ("Courts have occasionally treated the holding in U.S. Term Limits, Inc. v. Thornton, which found the qualifications for members of Congress enumerated in the Constitution as exclusive, applicable to presidential elections, too." (footnote omitted) (citing federal district court authority)). 


\section{state courts ${ }^{58}$ have taken a similar stance. So has much persuasive scholarly authority. ${ }^{59}$}

58 See, e.g., Cathcart v. Meyer, 88 P.3d 1050, 1071 (Wyo. 2004) (Voigt, J.) ("The general rule, and the better-reasoned rule, is that constitutionally prescribed qualifications for holding a constitutional office are exclusive."); Okla. State Election Bd. v. Coats, 610 P.2d 776, 778-79 (Okla. 1980) (Hodges, J.) ("The general rule is that when the constitution establishes specific eligibility requirements for a particular constitutional office, the constitutional criteria are exclusive. The legislature, except where expressly authorized to do so, has no authority to require additional or different qualifications for a constitutional office."); State ex rel. Chavez v. Evans, 446 P.2d 445, 448 (N.M. 1968) (per curiam) ("The state may provide such qualifications and restrictions as it may deem proper for offices created by the state; but for offices created by the United States Constitution, we must look to the creating authority for all qualifications and restrictions." (emphasis added)); Buckingham v. State ex rel. Killoran, 35 A.2d 903, 906 (Del. 1944) (Rodney, J.) ("It is the general law that where a constitution creates an office and prescribes the qualifications that the incumbent must possess, that the legislature has no power to add to these qualifications." (citing 1 Justice Thomas M. Cooley, A Treatise on the Constitutional Limitations Which Rest upon the Legislative Power of the States of the American Union 140 (Walter Carrington ed., 8th ed. 1927); Floyd R. Mechem, A Treatise on the Law of PubLic Offices And Officers $\S \S 65,98$, at 22, 39-40 (Chicago, Callaghan and Co. 1890); Montgomery H. Throop, A Treatise on the Law Relating to Public Officers and Sureties in Official Bonds $\S 73$, at 82-83 (N.Y., J.Y. Johnston Co. 1892))); Thomas v. Owens, 4 Md. 189, 1853 WL 2525, at *10 (1853) (Le Grand, C.J.) ("Where a constitution defines the qualification of an officer, it is not within the power of the legislature to change or superadd to it, unless the power be expressly, or by necessary implication, given to it . ..." (emphasis in the original)); see also, e.g., 63C Am. JuR. 2D Public Officers and Employees: Power of Legislature to Prescribe Qualifications $§ 51$ (2015) ("The legislature has no power to add to the qualifications, or to require different qualifications, for a constitutional office, unless the constitution, expressly or impliedly, gives the legislature the power to do so." (footnotes omitted)); 67 C.J.S. Officers and Public Employees: Power to Fix Qualifications and Disqualifications $\S 22$ (2015) ("[C]onstitutionally prescribed qualifications for holding a constitutional office are exclusive."); cf., e.g., H. B. Chermside, Jr., Annotation, Construction and Effect of Constitutional or Statutory Provisions Disqualifying one for Public Office Because of Previous Tenure of Office, 59 A.L.R. 2D 716, § 2[b] (originally published in 1958) ("[I]t has been held that where the qualifications for office are stated by the constitution, the legislature cannot add to them or change them by statute."); C. T. Foster, Annotation, Legislative Power to Prescribe Qualifications for or Conditions of Eligibility to Constitutional Office, 34 A.L.R. 2D 155, § 3 (originally published in 1954) ("According to a substantial amount of authority, where a constitution lays down specific eligibility requirements for a particular constitutional office, the constitutional specification in that regard is exclusive and the legislature (except where expressly authorized to do so) has no power to require additional or different qualifications for such constitutional office.").

59 See, e.g., William Josephson, Senate Election of the Vice President and House of Representatives Election of the President, 11 U. PA. J. Const. L. 597, 660 n.236 (2009) ("“[Alexander Hamilton's] view was upheld in Powell v. McCormack, 395 U.S. 486, 550 (1969), which held that when 'judging the qualifications of its members Congress is limited to the standing qualifications prescribed in the Constitution.' The same reasoning should apply to the qualifications for President and Vice President." (emphasis added)); Sean R. Sullivan, A Term Limit by any Other Name? The Constitutionality of State-Enacted Ballot Access Restrictions on Incumbent Members of Congress, $56 \mathrm{U}$. PitT. L. Rev. 845, 856-857 (1995) (restating Joseph Story's position in his Commentaries as "[s]ince the Constitution created both the offices of President and Representative, the qualifications that the Constitution enumerated for each office were the exclusive qualifications one would need to possess in order to hold office"); Matthew J. Franck, No, a Statute Can 't Keep Hillary From Being President, National Review: Bench Memos (Mar. 18, 2015, 1:41 PM), http://www.nationalreview.com/benchmemos/415603/no-statute-cant-keep-hillary-being-president-matthew-j-franck ("Last night on her Fox News program, Megyn Kelly was discussing the Hillary Clinton e-mail affair with Shannen Coffin . . . and after partially quoting 18 U.S.C. $\S 2071$, Kelly remarked that if Clinton was [sic] indeed guilty of destruction of documents, she would not only have committed a felony but 'she cannot be president.' ... [The question] is not so interesting, because the answer is so obvious, is whether this statute has any effect whatsoever on eligibility to be president. It doesn't, because it can 't." (emphasis added)); see also, e.g., MASKELL, supra note 5, at CRS-1 ("Although there may have been some credible minority argument concerning the ability of Congress or the states individually to set additional or different qualifications for federal office from those set out in the Constitution, it is now wellsettled 
Furthermore, the case for exclusivity in regard to the Constitution's express textual eligibility requirements for the presidency is stronger than the coordinate issue decided in Powell, i.e., the exclusivity of the Constitution's express textual qualifications for House seats. The power to judge members' qualifications is expressly and unambiguously committed to each house of Congress, ${ }^{60}$ but no such express power is unambiguously committed to Congress in regard to adjudicating a contest involving a presiden-

that the qualifications established in the U.S. Constitution are the exclusive qualifications for federal office ... and are not merely 'minimum' qualifications ...."); $c f$. id. at CRS-24 ("Thus, the fact of a criminal conviction could not be used to keep a candidate for federal office off of the ballot under state law ...."); $i d$. ("[T] he fact that an individual is in prison is also not necessarily a constitutional bar to or an automatic disqualification from running for and being elected to Congress."); id. at CRS-1 ("The constitutional history and case law demonstrate that such constitutional qualifications are fixed and may not be changed, added to, or subtracted from by Congress, nor by the state legislatures (other than by an amendment to the U.S. Constitution)."); CHAFETZ, supra note 1, at 171 (affirming that the Constitution's qualifications in regard to congressional seats are exclusive); Roderick M. Hills, Jr., A Defense of State Constitutional Limits on Federal Congressional Terms, 53 U. PITt. L. Rev. 97, 101 (1991) ("[T]o the extent that the Qualifications clauses were intended to exclude additions, they were intended to exclude additions by state and federal legislatures ...." (emphasis in the original)); id. at 119 ("A quick glance through Farrand's Debates indicates that Madison and other framers believed that no state or federal legislature could add qualifications to those required by the federal constitution." (footnote omitted)); cf., e.g., George W. McCrary, A Treatise on the American Law of Elections § 347, at 264 (Henry L. McCune ed., Chicago, Callaghan \& Co. 4th ed. 1897) ("Where the Constitution prescribes the qualifications for an office, the Legislature cannot add others not therein prescribed." (emphasis added)); John C. Yoo, In Defense of the Court's Legitimacy, 68 U. CHI. L. REv. 775, 785-86 (2001) (suggesting U.S. Term Limits, Inc. applies in the context of presidential elections). Compare, e.g., P. Allan Dionisopoulos, A Commentary on the Constitutional Issues in the Powell and Related Cases, 17 J. PuB. L. 103, 142 n.115 (1968) (“Actually the [A]ct of 1853 also permanently disqualified for any national office those public officials, who, having custody of public records, destroyed them." (emphasis added)), with Gordon, supra note 9, at 9 n.71 (explaining that "the application of these statutes [including Section 2071] to the [p]residency has never been [judicially] tested"). But see CHAFETZ, supra note 1, at 178-80 (describing pre-Powell decisions by the House and by the Senate to exclude members-elect for reasons unrelated to the Constitution's fixed textual qualifications, e.g., exclusions based on allegations of polygamy by LDS Church members who were elected to Congress); id. at 189-91 (discussing exclusion by the House of a member-elect, prior to Powell, based, in whole or in part, on his opposition to U.S. participation in World War I); THOMAS M. Cooley, The General Principles of Constitutional Law in the United States of America 285 (Andrew C. McLaughlin ed., Boston, Little, Brown, and Co. 3d ed. 1898) ("The Constitution and laws of the United States determine what shall be the qualifications for Federal offices . ..." (emphasis added)); THROOP, supra note 58, at 82 (explaining that the legislature has the power to prescribe qualifications "in addition to those prescribed by the constitution ... provided that they are reasonable"); Dionisopoulos, supra at $108 \mathrm{n} .16,111,116-21,142 \mathrm{n} .115$ (arguing, in a paper published prior to Powell, that Congress may add statutory qualifications in regard to congressional membership); but cf. AMAR, BIOGRAPHY, supra note 10, at 427 (suggesting that prior to 1922, a state legislature could "disqualif[y] all female candidates for president"); AMAR, supra note 22, at 289 ("Before 1920 [when the Women's Suffrage or Nineteenth Amendment was adopted], states could constitutionally keep women from ... appearing on the ballot as presidential candidates."); МЕCHEM, supra note 58, at 22-23 (noting that the legislature may prescribe additional qualifications where the constitutionally mandated qualifications are not "exclusive"); Muller, supra note 5, at 571-72. See generally John C. Eastman, Open to Merit of Every Description? An Historical Assessment of the Constitution's Qualifications Clauses, 73 Denv. U. L. Rev. 89, 124-27 (1995).

${ }^{60}$ See U.S. Const. art. I, § 5, cl. 1 ("Each House shall be the Judge of the Elections, Returns and Qualifications of its own Members ....”). 
tial candidate's, president-elect's, or President's eligibility requirements. ${ }^{61} \mathrm{It}$ would seem to follow that if Congress has no power to add to the standing qualifications of its own members, then it cannot add to the standing eligibility requirements for the other constitutionally-mandated elected federal positions, ${ }^{62}$ i.e., the President and Vice President.

For all these reasons, it seems likely that Powell is controlling, and that applying Section 2071's “office under the United States” language to the presidency is unconstitutional. Indeed, the more likely that Powell is seen as controlling because the constitutional principles at stake are clear, the less likely it is that Congress-whose members are presumed to understand the Constitution's broad structural requirements-intended its "office" language to apply to elected positions, such as the presidency. ${ }^{63}$

Nevertheless, it is possible to make a principled distinction between the facts and law at issue in Powell from the consequences of a potential Clinton-related prosecution and conviction under Section 2071. Powell involved a legislative investigation and adjudication culminating with a resolution of a single house to exclude a member-elect. Such quasi-judicial action by an elected chamber poses due process risks, particularly because the members are both the investigators and decision-makers, because the members are political partisans, and because the members decide by sim-

${ }_{61}$ See Muller, supra note 5, at 581 ("As a preliminary matter, the Constitution treats Congress's evaluation of executive and legislative qualifications quite differently. There is a "textually demonstrable commitment' to Congress to evaluate the qualifications of its own members; there is no such express commitment for its handling of presidential candidates." (quoting Powell) (footnote omitted)); id. at 584-89 (explaining competing views in regard to congressional control over qualifications disputes involving presidents and presidential candidates); $i d$. at 599-608 (explaining competing views in regard to state control over qualifications disputes involving presidents and presidential candidates). See generally U.S. Const. art. II; Ackerman \& Fontana, supra note 28 passim.

${ }^{62}$ See Franklin v. Massachusetts, 505 U.S. 788, 800 (1992) (O’Connor, J.) ("The new and pending bill recognizes this objection to the extent that the President is substituted for the Secretary of Commerce so that this function may be served by a constitutional officer." (quoting from a Senate report) (emphasis added)); id. at 809 n.6 (Stevens, J., concurring) ("[I]t were better to name a constitutional officer rather than a statutory officer." (quoting Senator Vandenberg's floor statement) (emphasis added)); 63C AM. JuR. 2D Public Officers and Employees: Constitutional Offices $\S 15$ (2015) ("A constitutional office is one created by the United States Constitution or by a state constitution, as distinguished from an office created by statute." (footnote omitted) (emphasis added)); Chief Justice Harry Lee Anstead et al., The Operation and Jurisdiction of the Supreme Court of Florida, 29 Nova L. REv. 431, 510 n.448 (2005) ("[A] constitutional office is one created by the constitution ....".). See generally FAQs, Compensation Board: The Commonwealth OF VirGinia, http://www.scb.virginia.gov/faqsmenu.cfm (last visited Apr. 17, 2015) ("In Virginia, the public elects ... its constitutional officers, so named because their offices are specifically established by the Constitution of Virginia." (emphasis added)).

63 See, e.g., United States v. Morrison, 529 U.S. 598, 607 (2000) (Rehnquist, C.J.) (referring to a "presumption of constitutionality" in regard to congressional acts); INS v. Chadha, 462 U.S. 919, 944 (1983) (Burger, C.J.) ("We begin, of course, with the presumption that the challenged statute is valid."); United States v. Harris, 106 U.S. 629, 635 (1883) (Woods, J.) ("Proper respect for a coordinate branch of the government requires the courts of the United States to give effect to the presumption that $[\mathrm{C}]$ ongress will pass no act not within its constitutional power. This presumption should prevail unless the lack of constitutional authority to pass an act in question is clearly demonstrated."). In the Carolene Products footnote, the Court stated: "There may be narrower scope for operation of the presumption of constitutionality when legislation appears on its face to be within a specific prohibition of the Constitution, such as those of the first ten Amendments, which are deemed equally specific when held to be embraced within the Fourteenth." United States v. Carolene Prods. Co., 304 U.S. 144, 152 n.4 (1938) (Stone, J.) (emphasis added). 
ple majority voting. By contrast, Section 2071 is a provision of a federal statute, part of the supreme law of the land, ${ }^{64}$ subject to bicameral passage and presidential veto. ${ }^{65}$ Moreover, Section 2071 contemplates the full array of traditional judicial due process rights, including: an independent Article III judge, a right to a grand jury, and a right to an impartial (unanimous) jury. ${ }^{66}$ Given the greater respect due a statute (as opposed to a single-house resolution), and the greater procedural protections a defendant has in the context of a Section 2071 criminal prosecution (as opposed to a congressional investigation), a court might distinguish Powell and uphold the constitutionality of a federal statutory provision (such as Section 2071) even in cases where the statutory provision has the effect of adding qualifications to elected federal positions, ${ }^{67}$ including the presidency.

64 See U.S. Const. art. VI, cl. 2 ("This Constitution, and the Laws of the United States which shall be made in Pursuance thereof; and all Treaties made, or which shall be made, under the Authority of the United States, shall be the supreme Law of the Land; and the Judges in every State shall be bound thereby, any Thing in the Constitution or Laws of any State to the Contrary notwithstanding.").

65 See U.S. Const. art. I, § 7, cl. 2 ("Every Bill which shall have passed the House of Representatives and the Senate, shall, before it become a Law, be presented to the President of the United States; If he approve he shall sign it, but if not he shall return it, with his Objections to that House in which it shall have originated, who shall enter the Objections at large on their Journal, and proceed to reconsider it. If after such Reconsideration two thirds of that House shall agree to pass the Bill, it shall be sent, together with the Objections, to the other House, by which it shall likewise be reconsidered, and if approved by two thirds of that House, it shall become a Law.").

66 See U.S. Const. art. III (providing for independent judges); $i d$. at amend. V (providing for grand jury rights); $i d$. at amend. VI ("In all criminal prosecutions, the accused shall enjoy the right to a speedy and public trial, by an impartial jury of the State and district wherein the crime shall have been committed, which district shall have been previously ascertained by law, and to be informed of the nature and cause of the accusation; to be confronted with the witnesses against him; to have compulsory process for obtaining witnesses in his favor, and to have the Assistance of Counsel for his defence."); Apodaca v. Oregon, 406 U.S. 404 (1972) (holding nonunanimous 9-3 or 10-2 verdicts in criminal cases is permissible for state trials, but not for federal trials); Johnson v. Louisiana, 406 U.S. 356 (1972) (same).

67 See generally Dionisopoulos, supra note 59 passim. In opining on a somewhat analogous issue, some commentators have argued that the purported exclusivity of impeachment in regard to removing Article III judges may be supplemented by a federal trial imposing removal-where authorized by statute - as a punishment for a criminal conviction (or even, perhaps, in connection with a civil trial). See, e.g., Peter M. Shane, Who May Discipline or Remove Federal Judges? A Constitutional Analysis, 142 U. PA. L. Rev. 209, 230 n.72 (1993) ("Professor Amar interprets the Constitution as implying 'that generally all federal officials are subject to the general criminal laws passed by Congress.' Akhil R. Amar, On Judicial Impeachment and its Alternatives-Remarks Prepared For the National Commission on Judicial Discipline and Removal 3 (Dec. 18, 1992) (unpublished manuscript, on file with author). [Amar] argues that because all federal officials could thus be made subject to a federal statute imposing capital punishment for certain federal crimes, such as murder in the District of Columbia, removal from office should be regarded as simply one of the wide range of lesser penalties embraced by Congress's near-plenary power to prescribe sanctions for federal offenses."); see also, e.g., Michael J. Gerhardt, The Constitutional Limits to Impeachment and Its Alternatives, 68 Tex. L. Rev. 1, 81 (1989) ("Thus, the [1790 AntiBribery] Act indicates that the First Congress anticipated and accounted for criminal prosecutions preceding impeachments as well as allowed for removal other than by formal impeachment and conviction."); Saikrishna Prakash \& Steven D. Smith, How To Remove a Federal Judge, 116 Y ALE L.J. 72, 129-30 (2006) (arguing that Congress may provide for judicial removal in consequence of a criminal conviction); $i d$. at 130-31 (arguing that Congress may provide for judicial removal in consequence of a civil action). 


\section{B. Constitutional Structure}

Frequently, the Constitution is interpreted constructively, through implication, ${ }^{68}$ and by inferences about its global structure. ${ }^{69}$ Two such structurally related policy concerns merit consideration.

First, the Framers "desire[d] to make the office [of President] as politically independent of Congress as possible." 70 Thus, to allow Congress to manipulate presidential qualifications risks making a candidate or sitting President

68 E.g., INS v. Chadha, 462 U.S. 919, 946 (1983) (Burger, C.J.) ("The very structure of the Articles delegating and separating powers under Arts. I, II, and III exemplifies the concept of separation of powers ...."); Collector v. Day, 78 U.S. 113, 124, 127 (1870) (Nelson, J.) (interpreting the Constitution based on "necessary implication[s]" arising from the Constitution's global structure); M'Culloch v. Maryland, 17 U.S. (4 Wheat.) 316, 407 (1819) (Marshall, C.J.) ("A constitution, to contain an accurate detail of all the subdivisions of which its great powers will admit, and of all the means by which they may be carried into execution, would partake of the prolixity of a legal code, and could scarcely be embraced by the human mind. It would, probably, never be understood by the public. Its nature, therefore, requires, that only its great outlines should be marked, its important objects designated, and the minor ingredients which compose those objects, be deduced from the nature of the objects themselves. That this idea was entertained by the framers of the American constitution, is not only to be inferred from the nature of the instrument, but from the language. . . . In considering this question, then, we must never forget that it is a constitution we are expounding." (emphasis added)). But see Amalgamated Soc'y of Eng'rs v Adelaide S.S. Co. (1920) 28 CLR 129, 145 (Knox, C.J., Isaacs, Rich and Starke, JJ.) (Austl.) (rejecting constitutional interpretation via "implication" absent a textual anchor in the constitution).

${ }_{69}$ See Printz v. United States, 521 U.S. 898, 905 (1997) (Scalia, J.) ("Because there is no constitutional text speaking to this precise question, the answer to the [petitioners'] challenge must be sought in historical understanding and practice, in the structure of the Constitution, and in the jurisprudence of this Court." (emphasis added)); id. at 918 (opining on the "structure of the Constitution"); Principality of Monaco v. Mississippi, 292 U.S. 313, 322 (1934) (Hughes, C.J.) (adjudicating controversy through the prism of the Constitution's "essential postulate[s]"). See generally Charles L. Black, JR., Structure and Relationship in Constitutional Law (1969).

70 Jack N. Rakove, Confessions of an Ambivalent Originalist, 78 N.Y.U. L. Rev. 1346, 1353 (2003). See, e.g., U.S. Const. art. II, $\S 1$, cls. 2-3 (establishing that the President and Vice President are to be elected by means of a system of electors, who may hold neither congressional seats nor appointed positions in the Executive or Judicial Branches); id. at art. II, § 1, cl. 7 ("The President shall, at stated Times, receive for his Services, a Compensation, which shall neither be increased nor diminished during the Period for which he shall have been elected ...."); Steven G. Calabresi \& Joan L. Larsen, One Person, One Office: Separation of Powers or Separation of Personnel?, 79 Cornell L. Rev. 1045, 1094 (1994) ("Of course, the [Incompatibility] Clause is not the only constitutional impediment to the development of an American parliamentary regime. Indeed, it is the election of the President independently of Congress, and his ability to retain office even when he does not command the confidence of the legislature, that are commonly cited as defining characteristics of American Presidential government."); Vasan Kesavan, Is the Electoral Count Act Unconstitutional, 80 N.C. L. REv. 1653, 1764-65 (2002) ("We should remember that of all the methods to elect the President considered by the Framers the one most emphatically rejected was election of the President by the legislature. The Framers rejected the parliamentary system for good reason: to create an independent and firm Executive." (footnote omitted)); Norman R. Williams, Reforming the Electoral College: Federalism, Majoritarianism, and the Perils of Subconstitutional Change, 100 GEO. L.J. 173, 180 (2011) ("The Framers adopted this system of indirect election so as to provide the President with a degree of independence from Congress. Were the President selected by Congress - the principal alternative to the Electoral College considered by the Framers - the Framers feared that he would be too dependent on Congress and that potential candidates for the office would seek congressional support by making undesirable, if not downright corrupt, promises in return for such support." (citing Farrand's Records)); cf., e.g., Nathan L. Colvin \& Edward B. Foley, The Twelfth Amendment: A Constitutional Ticking Time Bomb, 64 U. Miami L. Rev. 475, 487-88 (2010) ("Republican Senator Charles Pinckney, a Framer of the Constitution, gave a strong speech [prior to the 1800 presidential election which] focused on the 
dependent on Congress for election or re-election. Second, the Framers envisioned the People ${ }^{71}$ choosing the President indirectly through presidential electors. ${ }^{72}$ Again, allowing Congress to manipulate presidential qualifications risks Congress' choosing the President, rather than the People of the United States. ${ }^{73}$

To the extent that Section 2071 applies to the presidency, both structural concerns discussed above counsel against upholding its constitutionality. Still, such atextual structural concerns are largely intuition-driven and impressionistic. Such concerns may well have weight with some audiences, including some judges, but not with others. ${ }^{74}$

idea that the Constitution intended to prevent congressional interference with the presidential election, which might in turn compromise the President's independence.").

However, it should also be noted that in circumstances where the electoral college fails to select a President and Vice President, it is the House which chooses the President, and the Senate which chooses the Vice President. See U.S. Const. art. II, § 1, cl. 3, amended by U.S. Const. amend. XII; Josephson, supra note 59 passim.

71 See, e.g., Letter from James Madison to George Hay (Aug. 23, 1823), in 3 The Founders' ConstituTION 556-57 (Philip B. Kurland \& Ralph Lerner eds., 1987) ("The district mode [of popular election of the electors] was mostly, if not exclusively in view when the Constitution was framed and adopted ...."); Tillman, supra note 23, at 613-15 (collecting multiple statements in The Federalist, made by Alexander Hamilton and John Jay, which are consistent with Madison's 1823 letter). But compare Tillman, supra note 23, at 613 ("The Constitution of 1787 committed the selection of Senators to the state legislatures and left the selection of presidential electors to the discretion of the state legislatures: the 'people' played no direct role and played no role as a matter of right."), with Vikram Amar \& Alan Brownstein, Bush v. Gore and Article II Pressured Judgment Makes Dubious Law, 48 Fed. Law. 27, 31 (March/April 2001) ("[A]t the Philadelphia Convention, Madison described the electoral college provisions of the final draft as providing that the President is now to be elected by 'the people.' And at the Virginia ratifying convention, Madison stated that the Constitution provided that the President was to be chosen by 'the people' at large.").

72 See U.S. Const. art. II, $\S 1$, cl. 2 ("Each State shall appoint, in such Manner as the Legislature thereof may direct, a Number of Electors, equal to the whole Number of Senators and Representatives to which the State may be entitled in the Congress: but no Senator or Representative, or Person holding an Office of Trust or Profit under the United States, shall be appointed an Elector."); $i d$. at art. II, $\S 1, \mathrm{cl} .3$ (providing for the election of the President and Vice President by electors).

73 See 5 Debates on the Adoption of the Federal Constitution in the Convention Held at PhilaDELPHIA, IN 1787, at 404 (Jonathan Elliot ed., Washington, n.p. Supp. 1845) (James Madison, on Aug. 10, 1787, stating: "The qualifications of electors and elected were fundamental articles in a republican government, and ought to be fixed by the Constitution. If the legislature could regulate those of either, it can by degrees subvert the Constitution." (emphasis added)); see also Amar \& Brownstein, supra note 71, at 31.

74 See Eugene Volokh, No, Hillary Clinton wouldn't be legally ineligible for the Presidency even if she had violated government records laws, The Washington Post-Volokh Conspiracy (Aug. 26, 2015, 12:54 PM), https://www.washingtonpost.com/news/volokh-conspiracy/wp/2015/08/26/nohillary-clinton-wouldnt-be-legally-ineligible-for-the-presidency-even-if-she-had-violated-government-records-laws (quoting Attorney General Mukasey's retraction, apparently based on his considering (or reconsidering) the application of Powell and coordinate structural considerations to the issue at hand). But see supra note 12 (quoting Investor's Business Daily article, a newspaper article, asserting the legal populist position); supra note 14 (collecting multiple statements by former Attorney General Mukasey asserting the legal populist position). 


\section{Conclusions}

Does Section 2071's “office under the United States" language apply to the presidency? I expect the rider on the Clapham omnibus thinks so, ${ }^{75}$ as do others from more rarefied academic ${ }^{76}$ and judicial circles. ${ }^{77}$ But historical materials ${ }^{78}$ and established principles of statutory interpretation ${ }^{79}$ cut the other way.

As to Section 2071's constitutionality, Powell and its progeny, ${ }^{80}$ along with structural considerations,${ }^{81}$ lean against upholding the statute if applied to elected federal positions. But we cannot predict with certainty how the courts will decide this question should it come before them. It seems the better view is that if Secretary Clinton prevails in the election, then a Section 2071 conviction would not bar her from the presidency as a formal legal matter. However, such a conviction (or, perhaps, even a mere prosecution) might effectively derail any ongoing presidential campaign. ${ }^{82}$ This would be especially true if the prosecution is controlled by a member of her own party, i.e., President Barack H. Obama.

75 See supra Part II[A] (discussing the legal populist's position).

76 See supra notes $10 \& 15$, and accompanying text (discussing Professor Akhil Amar's position); supra note 12, and accompanying text (discussing other academic authority); supra Part II[B][3] (discussing post-Civil War scholarship, domestic and foreign).

77 See supra note 14, and accompanying text (discussing former Chief Judge Mukasey's position). But see supra note 74 (noting Mukasey's subsequent retraction).

78 See supra Part II[B][1]-[2] (discussing Washington's gift from the French ambassador, and the Hamilton list).

79 See supra Part II[C][1] (explaining that general "office" language in a statute does not reach the presidency); supra Part II[C][2] (explaining that interpretations of statutory language restricting the scope of democratic choice are not favored).

80 See supra Part III[A] (discussing Powell and its progeny in federal and state courts).

${ }^{81}$ See supra Part III[B] (discussing constitutional structure in regard to presidential independence, popular election of the President, and structural limits on congressional power over the process in which electors are chosen and elect the President).

82 If a person were prosecuted under Section 2071 while a candidate or president-elect, and that person were elected and then became President, then continuing the federal prosecution against a sitting President would pose certain practical problems, particularly for unitarists who believe the President has control over all federal law enforcement. See, e.g., Michael Stokes Paulsen, Nixon Now: The Courts and the Presidency After Twenty-five Years, 83 MinN. L. Rev. 1337, 1342 (1999) (arguing "contra United States v. Nixon ${ }_{[\text {'] }}$ [418 U.S. 683 (1974) (Burger, C.J.)], that the President of the United States must have the final say as to all matters concerning the execution of the laws of the United States by officers of the executive branch"); $i d$. at 1390-97 (same). Likewise, if a sitting President were convicted under Section 2071, one might very well wonder if the President could pardon herself. See U.S. Const. art. II, § 2, cl. 1 (Pardon Clause: "[The President] shall have Power to grant Reprieves and Pardons for Offences against the United States, except in Cases of Impeachment."); Kalt, supra note 5, at 39-60; Brian C. Kalt, Note, Pardon Me?: The Constitutional Case Against Presidential Self-Pardons, 106 YALE L.J. 779 (1996). 
